\title{
TOURISM DISCOURSE REVISITED: AN ANALYSIS OF EVALUATIVE STRATEGIES IN TOURIST BROCHURES FROM A SYSTEMIC FUNCTIONAL LINGUISTICS PERSPECTIVE
}

\author{
Alireza Jalilifar \\ Shabid Chamran University of Abvaz, Iran \\ ar.jalilifar@gmail.com \\ YASAMIN MORADI \\ Shabid Chamran University of Abvaz, Iran \\ moradiyasamin@gmail.com
}

\begin{abstract}
Today, studying tourism discourse has become widespread among scholars in the field of text analysis. However, few, if any, studies which have addressed the language of tourism have examined the verbal content of travel brochures from the point of view of the appraisal model. The major questions addressed in this study pertain to Graduation strategies as part of appraisal strategies in the discourse of tourism as well as the lexico-grammatical resources for the coding of these strategies in texts. The dataset comprised 50 e-brochures released by tour operators across the United States within the period 2012 to 2013. First, the data were examined quantitatively to identify the statistical variations in utilizing Graduation strategies in tourist brochures. The preferences for lexicogrammatical resources for the construal of these strategies were also illustrated in light of a qualitative analysis. The results of the study revealed that the discourse of travel brochures is loaded with Graduation strategies. The subsystems within the system of Graduation were shown to serve as strong tools in promoting various aspects of tourist destinations such as the number and distribution of tourist sites over an area.
\end{abstract}

Keywords: Appraisal, Graduation strategies, Language of tourism, Tourist brochures. 


\title{
EL DISCURSO TURÍSTICO REVISITADO: UN ANÁLISIS DE LAS ESTRATEGIAS EVALUATIVAS EN LOS FOLLETOS TURÍSTICOS DESDE UNA PERSPECTIVA LINGÜÍSTICA SISTÉMICO-FUNCIONAL
}

\begin{abstract}
RESUMEN. El análisis del discurso turístico se ba extendido boy en día entre los estudiosos en el campo del análisis textual. Sin embargo, muy pocos estudios, si alguno, que han abordado el lenguaje del turismo han examinado el contenido verbal de los folletos de viajes desde el punto de vista del modelo de valoración. Las principales cuestiones que se plantean en este estudio tienen que ver con las estrategias de gradación como parte de las estrategias de valoración en el discurso turístico y con los recursos léxico-gramaticales para el codificado de dichas estrategias en los textos. El conjunto de datos comprende 50 folletos online emitidos por operadores turísticos en Estados Unidos en el período 2012 a 2013. En primer lugar, los datos se han examinado cuantitativamente para identificar las variaciones estadísticas a la hora de utilizar estrategias de gradación en dichos folletos. Se han analizado también las preferencias léxico-gramaticales para la interpretación de estas estrategias desde una perspectiva cualitativa. Los resultados del estudio han revelado que en el discurso de los folletos turísticos abundan las estrategias de gradación. Los subsistemas dentro del sistema de gradación han demostrado ser herramientas sólidas para promocionar los destinos turisticos, concretamente en lo que respecta al número y la distribución de lugares turísticos en un área.
\end{abstract}

Palabras clave: modelo de valoración, estrategias de gradación, lenguaje del turismo, folletos turísticos.

Received 21 March 2018 Revised version accepted 18 December 2018

\section{INTRODUCTION}

Today, tourism is known as one of the most important businesses throughout the world. The tourism industry owes much of its success to the way tourist destinations are advertised, that is, to the content of brochures, leaflets, travelogues, etc. This makes the language of tourism of paramount importance. Whereas some researchers consider the language of tourism to be general but only more fertile in diction and style (e.g., Gotti 2003), other scholars regard the tourism language to be the language of promotionl and popularization (e.g., Thurot 1989), is a highly organized and encoded system in its own right (Said 1991: 21) which deserves careful consideration. The language of tourism is also described as a discourse object (Bhatia 1993) which falls within the broad category of promotional discourse or the study of attitudes in the social sciences (Dillard and Pfa 2002).

Due to the significant role that the media play in business activities including the tourism industry (Locksley 2009), scrutinizing informative promotional media 
TOURISM DISCOURSE REVISITED: AN ANALYSIS OF EVALUATIVE STRATEGIES...

(Choi, Xinvan and Alastair 2007) such as websites (Burns and Robertson 1999; Doolin, Burgess and Cooper 2002; Hallett and Kaplan-Weinger 2010; Lähteenmäki 2012), publicity programs (Dore and Crouch 2003) and TV commercials (Pan, Tsi and Lee 2011) has contributed to the tourism literature.

What constitutes the language of tourism? Which aspects of this language do tourist text designers need to focus on? Across the literature of tourism, various studies within different theoretical frameworks have tried to reveal different aspects of the language of tourism. For instance, taking a sociolinguistic approach, certain studies have aimed at describing how intelligently promoters in the tourism industry exert social control over the consumers (Dann 2012) while maintaining the idea that tourists are given absolute freedom (Rokowski 2001). In serving the purpose of promotion here, the language of tourism becomes highly value-laden and ideological biased (Bhatia 1993).

Critical Discourse Analysis has also been applied to a number of studies to uncover the changes that have appeared as a result of new tendencies in tourism sectors (Bruner 1991; Hallett and Kaplan-Weinger 2010; Jonsson and Syssner 2011). For instance, a new positive imagery of Chinatown replaced its demeaning face as a result of the change in the discourse of the brochures promoting this district to attract visitors (Santos, Belhassen and Caton 2009). This indicates how texts can camouflage important aspects of the places that they purport to describe using effective rhetorical devices.

In a review of the literature on advertisements, there are studies employing Systemic Functional Linguistics (hereafter SFL) as their theoretical framework, such as Patpong (2009) who discovered that the use of language in amulet advertisements is one example to demonstrate the persuasive use of language. Yet Patpong deals with the discourse of advertisements in general, but not tourism discourse in particular. Among the studies on travel brochures, some tend to focus solely on the verbal content of brochures (Mocini 2009; Cui, Lu and Hong 2012) while others, in line with the idea of multimodality of travel brochures (Kress and van Leeuwen 1996; Scollon and Levine 2004; van Leeuwen 2004), investigate both linguistic and visual elements deployed in tourist texts to draw an appealing image of the destination (Ling Ip 2008). Some of these studies (e.g., Kress and van Leeuwen's 1996) have suggested context bound patterns, but it seems that globalization has led to outstretch these strategies for creating images even in eastern countries.

As an offshoot of SFL, the appraisal model (Martin and White 2005) has also been extensively deployed to study the discourses of various genres, including academic discourse (Hood 2006; Jalilifar, Hayati and Mashhadi 2012; Liu 2013; 
Mei and Allison 2003), journalistic discourse (A'Beckett 2010; Liu and Stevenson 2013; White 2001, 2003) narrative discourse (Macken-Horarik 2003), as well as the discourse of telephonic conversations (Wan 2008). Demonstrating a vivid interactive context, the above studies have endorsed that these discourses are not value-free but value-laden contextualised, ideological and dialogic. Tourism discourse, however, has received scant attention from scholars working within the area of the language of evaluation. Thus, the present study aims to partly bridge the gap in research on evaluative strategies through working on Graduation resources deployed in the language of travel brochures as a promotional strategy to grab the attention of potential tourists. Since tourism discourse is known as a promotional discourse, the main purpose in writing tourist texts is promoting the services and sites in touristic areas. Graduation is related to tourism discourse in that it is concerned with toning the values up. Graduation also comprises toning the values down, but this is of little concern in tourism discourse. Graduation, as a system within the appraisal model, is concerned with up-scaling and downscaling of values. All attitudinal meanings, namely, the values of affect, judgment, and appreciation as well as engagement are gradable resources (Hood and Martin 2007; Martin and White 2005: 135). Force and focus are the two main areas within which the values are scaled in the system of Graduation. Meanings are graded by either a scale from low to high intensity or from a core to marginal membership. The former scale is referred to as force while the latter is termed focus. Graduation is made either separately or as infused with the attitudinal values (Martin and White 2005: 141). Force and focus are also subsequently divided into further subsystems. Force is concerned with evaluations in terms of the degree of intensity or amount, hence is subdivided as quantification and intensification. Focus, on the other hand, deals with sharpening or softening the boundaries between categories.

Notwithstanding the studies cited above, there is a lot to discover about the language of tourism and the lines of investigation are still open. Over the last few decades, tourism industry has been considered as a great source of financial benefit to many countries around the world. This makes the discourse of tourism of paramount importance since a better understanding of the underlying systems for meaning-making in the discourse of tourism would aid the designing of tourist texts which may attract a larger number of people. Studying the language of tourism from an SFL point of view is justified by the fact that SFL is a broad framework for text analysis, an evaluative tool which helps us to understand the construction of texts. SFL provides us with a comprehensive view of the systems deployed in the language of tourism for the purpose of meaning-making. This can, in turn, lead the tourist text developers to design brochures potentially capable of affecting a greater number of clients. Taking an SFL approach to the study 
of the language of travel brochures is different from taking other approaches in that the former helps us to view the meanings proposed in tourist brochures not only in terms of the language choices used for their construal, but also with regard to the functions they serve. The appraisal model is regarded as a discourse semantic system within SFL for analyzing interpersonal meanings. Accordingly, employing this framework for the study of travel brochures helps with knowledge construction and locating interpersonal meanings in such texts. This may, in turn, help tour operators raise the power of travel brochures in influencing the potential tourists (Hood 2004). Furthermore, the results of the study provide an assurance on the efficiency of the framework as a useful tool for text analysis. Generally, the study reveals that appraisal, due to its comprehensiveness, has a great potential for the analysis of texts within the genre of tourism. The general intention of the researchers in conducting the present study is summarized in the following research questions:

1. In what ways and through what resources are Graduation values realized in travel brochures?

2. Do the identified resources and patterns through which different values are graded serve any significant function in the context of tourism?

3. Are the frequencies of subsystems linked to the efficiency of the travel brochures, that is, to their power in attracting potential customers?

\section{METHODOLOGY}

\subsection{ANALYTICAL FRAMEWORK}

The appraisal taxonomy (Hood and Martin 2007; Martin and White 2005) which provides a general framework for any study in evaluation shapes the background of this study. According to Bednarek (2010: 32), the appraisal model is "the only systematic, detailed and elaborate framework of evaluative language" among critical approaches to text evaluation. This model developed by Martin and White (2005) is an extension of the interpersonal metafunction of the language within the SFL framework. Appraisal is a model of interpersonal meaning, one of the three types of meaning (ideational, interpersonal, and textual) that SFL accounts for. In general, the model comprises three major systems, namely, attitude, engagement, and Graduation. These systems are divided into different subsystems which are, in turn, composed of various subcategories.

As one of the systems of the appraisal model, Graduation is concerned with up-scaling and down-scaling of values. All attitudinal meanings, namely, the values of affect, judgment, and appreciation as well as engagement values hold the general property of being gradable (Hood and Martin 2007; Martin and White 
2005). The meanings are graded either according to their intensity or amount or based on prototypicality. Graduation according to intensity or amount, known as force, applies to categories which are scalable based on their size, vigor, extent, proximity, etc. Graduation according to prototypicality, termed focus, is applied to categories which are not scalable. Up-scaling and down-scaling within the category of focus are referred to as sharpening and softening. (Martin and White 2005). Force and focus are also subsequently divided into further subsystems.

Analyzing the system of Graduation in this study and overlooking the other two systems, namely the systems of attitude and engagement, is mainly due to the generality of Graduation, that is, the other two systems are greatly influenced, or graded (to put it more precisely) by Graduation values which makes this system worth studying in its own right. On the other hand, focusing exclusively on Graduation resources provides an opportunity for a more comprehensive and detailed analysis of this system of appraisal.

\subsection{THE DATA}

The data used in the present study, comprised sample descriptions taken from travel brochures featuring various tourist destinations. To make sure that the brochures are primarily targeted at an English-speaking readership, travel brochures published across the United States were chosen as the data in the study. For the purpose of fair distribution, one brochure was taken from every state of America resulting in the total number of 50 brochures. Since the printed version of the brochures was not easily accessible, e-brochures were taken as the data. In some cases, the PDF version of the brochures was used, but in other cases where the consulted tourism websites had not provided the PDF version, the textual information of the selected brochures as well as the websites' email addresses was copied and saved in text documents to be later used for data analysis. The other criterion for data collection was that the brochures were necessarily released within the period 2012 to 2013 to minimize variation due to the variable of time.

Almost all of the brochures were selected from top tour operators, that is, in cases where there were different competing operators providing tourist brochures featuring destinations within a single state, the tour operator whose website was most visited was selected as the source for data collection. In certain cases where the websites of tour operators from a particular state were not directly accessible, the required brochures were collected from other tourism websites which contained brochures from all over the world. In these few cases, the requirement of consulting top tourism websites was not necessarily observed due to lack of websites to choose from. 
Since the collected brochures were inconsistent with regard to their length, the average of the brochures' word count was calculated (350 words was considered as the minimum length), and in cases where there were different brochures from a single state which met all the criteria for data collection but were of varying lengths, the one whose word count was not far more than 350 was preferred over other brochures. The shortest brochure consisted of 350 words, while, the longest one contained 740 words. In addition, no special criteria were set on the type of destinations being promoted by the brochures, but that they covered natural wonders across the United States.

The collected data for the present study were of two types. The first dataset, which comprised about $95 \%$ of the data, were regular tourist brochures published by tour operators across the United States and were accessed through the websites of those operators. The second dataset contained travel guides provided by the official tourism bureaus within each state. In certain cases, e-brochures from few states (Connecticut, Maryland, and Maine) were not available or the accessed brochures did not meet the criteria set by this study in terms of the year of publication or the length. Therefore, the travel guides of those states, produced by tour operators, were selected to be analyzed instead. Although tourist brochures and travel guides are two different genres of tourism advertising, they are both regarded within the general category of promotional discourse, and when it comes to promoting a certain destination the language as well as the techniques employed in both genres are almost the same. One of the differences between travel brochure and travel guides lies in their length. Travel guides are of much greater length compared to travel brochures. They usually start with a few accounts on the tour operator and the services it provides. This is often followed by the table of contents, after which different destinations of the state are promoted. The order of the destinations promoted is either determined alphabetically or with regard to their geographical conditions or based on other criteria set by the travel guide developers. In order to have compatible sets of data in terms of length, in each travel guide, the first section which promoted a destination and whose word count was at least 350 was selected to be analyzed.

\subsection{PILOT STUDY}

The data were analyzed manually, hence carrying the risk of human error. For the purpose of reliability and to locate the potential errors, the study was first piloted based on $20 \%$ of the data. To develop a method to be deployed in the pilot, previous literature was examined to identify the methods used in studies having similar objectives. Firstly, the selected brochures were coded based on the 
appraisal taxonomy obtained from Martin and White (2005); that is, the values of Graduation were all identified and characterized within the selected set of texts which constituted 10 out of the total number of 50 brochures. The quantitative analysis proceeded up to two levels within the Graduation system; in other words, the instances of the two main subsystems within the system of Graduation, namely, force and focus were marked in the brochures studied which were, then, characterized and calculated separately in relation to one smaller point in delicacy within each subsystem (e.g., Graduation-force-quantification). It is noteworthy that attitudinal meanings can be realized either directly (inscribed attitude) or less directly (invoked attitude). Analyzing the data revealed that within the discourse of tourism the first trend is highly preferred. For this reason, the analyst only focused on identifying the instances of inscribed attitude and the few examples of invoked attitude within the data were not included in the analysis.

Fourteen items of Graduation were then selected, every single item providing two instances from each part of the Graduation model, up to the point studied, as presented within their contexts. Each selected item was initiated with the analysts' judgment on the two instances provided as shown below:

(Graduation $>$ Force $>$ Intensification)

A. Nature lovers can photograph the highest waterfall east of the Mississippi... Agree Disagree

The items were then distributed to five experts who had worked and published papers in the field of Systemic Functional Linguistics, and more importantly the appraisal model. Ethical considerations were first met by informing the experts of the research purpose and the procedures to be followed before they were given the items. They also indicated that their participation is voluntary. Since the five respondents were not easily accessible, the distribution of the items was made through e-mail. There was no significance in assigning a time limit for filling in the items, and the lack of time restriction raised the chance of a more careful analysis on the part of the respondents. They were asked to verify the analysts' judgments, that is, to decide whether they agreed or disagreed with what was identified and coded. In case of disagreement, the respondents were asked to provide their own judgment. Due to the fact that these items were of dichotomous choices, namely, agree and disagree, Kuder-Richarson Formula 20 was applied to measure the internal consistency of the analysis. The analysts' judgments were mostly agreed upon, and the reliability coefficient 0.83 was verified. The required rectifications were carried out by the researchers on those parts which were considered to be problematic. This was done with the help of those respondents locating the problems as well as consulting other respondents 
TOURISM DISCOURSE REVISITED: AN ANALYSIS OF EVALUATIVE STRATEGIES...

for a more confident decision, and then the whole set of texts were analyzed employing the same procedure.

\subsection{PROCEDURE}

After the pilot study, each brochure was worked through searching for the inscribed values of Graduation which were, then, coded and classified in relation to categories of the appraisal model. Since the discourse of tourism tends to speak in positive terms of the destinations it promotes and the services it offers, negative inscriptions were scarcely found within the brochures analyzed. As a result, the focus of the study was only on positive values of Graduation.

Having analyzed the data both quantitatively and qualitatively, the authors made a list of those propositions over the coding of which we were dubious and they were finally identified and coded through consulting and negotiation. To ensure the intra-rater reliability, however, the analysis was carried out twice by one of the researchers within a time interval of 10 days, and no major discrepancy was observed between the two sets of coding decisions. Following Zikmund (2008) who defines content validity as the subjective agreement among professionals that a scale logically appears to reflect accurately what it aims to measure, the content validity of the present scale was guaranteed through an extensive review of literature (Macken-Horarik 2003; Hood 2006; Wan 2008; A'Beckett 2010).

During the analysis, there were frequent cases where an individual lexical item was used several times in a single brochure. Although the lexical item served the same function in all instances and the coding was the same, the word was used to appraise a different entity in each repetition. Thus, all instances of the same word were maitained in the quantitative analysis. In other cases, however, an individual lexical item repeated several times in the same brochure was coded differently. This is quite convincing with regard to the fact that within the framework of SFL, all texts are interpreted in relation to the functions they serve within their context.

Intensifications within the system of Graduation are, in many instances, realized through the comparative and superlative form of adjectives. Since comparatives and superlatives are made up of two morphemes (the base form of the adjective followed by a suffix used for grading the adjective), they could be either broken into two parts and coded separately or be considered as a single lexical item serving the purpose of Graduation. The latter was applied in the present study, since in case of irregular comparatives and superlatives, it was not precise enough to break the lexical items into their constitutive parts and code them on their own rights as there is no clear-cut boundary between the two morphemes. In 
addition, the latter choice was supported by Sinclair in his description of the term delexicalisation:

The meaning of words chosen together is different from their independent meanings. They are at least partly delexicalized. This is the necessary correlate of co-selection. If you know that selections are not independent, and that one selection is dependent on another, then there must be a result and effect on the meaning which in each individual choice is a delexicalisation of one kind or another. It will not have its independent meaning in full if it is only part of a choice involving one or more words. (Sinclair 1994: 23, as cited in Martin and White 2005: 143)

The data analysis was carried out on two levels: First, the data were coded, computed, and analyzed quantitatively using the Statistical Package for Social Sciences (SPSS). According to the respective objective of the study, the percentages and frequencies of the lexical items within the system of Graduation as well as its associated subsystems detected in the data were calculated. The second part of the analysis approached the data qualitatively wherein the lexical items and their contexts in each of the categories were analyzed so as to examine the word choices and general patterns as well as the functions these patterns serve in the promotional discourse of tourism.

\section{RESULTS AND DISCUSSION}

The goal of this study is to reveal how Graduation resources are exploited in tourism discourse for the purpose of evaluation. The results of the study are presented in this section along with a discussion on how the findings contribute to the goal of the study. First, the findings obtained in the light of the performed quantitative analysis are presented. These are then followed by the qualitative analysis which aims to uncover the patterns through which the resources of Graduation are realized.

The data revealed a great difference between the frequencies of the values of force and focus. More than 90\% of the inscribed values of Graduation were identified as force as displayed in Table 1. The two subcategories of force, namely, quantification and intensification, also manifested sharply different frequencies. A careful analysis of the coded values of force in the data marked a sharp preference for upgrading the entities quantitatively. As shown in Table 1, within the whole data set, 510 values were toned up quantitatively while the frequency of the values being intensified was not greater than 212. These findings verify the idea that language of tourism is the language of exaggeration, that is, tourist text writers tend to magnify the number of opportunities for recreation, and the services 
available. In other words, they make great use of the strategy of maximization which itself is construed through quantifying lexis. The same reason may also help with interpreting the difference between force and focus in terms of their frequency within the brochures. This latter difference can however be more logically described in relation to the notion of the scarcity of the values of focus in general discourse.

Table 1. Inscriptions of the System of Graduation.

\begin{tabular}{|l|l|l|}
\hline & \multicolumn{1}{|c|}{ Frequency } & \multicolumn{1}{c|}{ Percentage (\%) } \\
\hline Force & 722 & 93.76 \\
\hline Quantification & 510 & 70.63 \\
\hline Intensification & 212 & 23.13 \\
\hline Focus & 48 & 6.23 \\
\hline Sharpen & 44 & 6.09 \\
\hline Soften & 4 & 0.5 \\
\hline
\end{tabular}

Within the following parts, examples are provided on how this evaluation in terms of amount or intensity and softening or sharpening of boundaries is realized in the language of travel brochures.

\subsection{FORCE}

\subsubsection{Grammatical Structures Deployed in the Realization of Quantification}

Quantification is a means via which meanings can be graded up or down as force. Quantification involves grading in terms of Number, Mass, and Extent (Martin and White 2005), typically revealed in individual modifiers; that is, Isolation is the dominant mode for the construal of quantification. It is noteworthy that the quantified entity might be either concrete or abstract as shown in the following examples:

Modification of a Concrete Nominal Entity

...the only professional dinner theatre in Ohio.

...the Rocky Mountain National Park is full of outstanding views and a variety of wildlife.

In addition, numerous vineyards dot the countryside around Lexington...

There's a story in every small town, and an adventure around every bend 


\section{Modification of an Abstract Nominal Entity}

... discover the heritage of the United States' only native spirit.

... and every shopping fantasy can come true.

The following examples illustrate how the values of Quantification as Number and Mass are realized in grammar:

\section{Quantifying as a Specific Number ...with nearly a million acres...}

Another abundantly used value of quantification in the brochures was the quantifier one of. Tourism promoters attempt to denote the idea that the destination being promoted is one but not the only attraction within that area:

Brave the rapids on a white-water rafting trip, play one of our spectacular golf sources...

To the west you can see the Phantom Valley, one of the many sources of the Colorado River.

Quantification as Non-specific Numeration

Non-specific quantifiers such as some, dozens of, and plenty of were also deployed, some of which amplify the number of attractions within a touristic area:

....Texas has plenty to offer.

.... as some of the island's best surfing locations.

Infusing Processes as Amount

Shorebirds build in number through May...

Moreover, infused quantifications were spotted to a limited extent within the brochures as in:

Texas offers an abundance of fun for kids of all ages...

...which have provided a lifetime of memories to generations of visitors.

From major festivals to a wealth of unique shops...

...with stories of immense wealth..

...one of the best known beaches in the world bustling with shopping, restaurants and nightlife.

As can be seen in the examples above, quantification is deployed in the language of tourism to promote the touristic areas and the services provided by tourism sectors. The tourists are promised to have a great experience through the abundant opportunities for having fun. 
According to Martin and White (2005), extent covers the proximity as well as the distribution of entities in time or space. Distribution is concerned with the degree to which entities are "long-lasting" or "widely-distributed", while proximity involves the degree of recency or adjacency (pp. 148-149). The following are a range of structures via which grading as extent is realized:

\section{Extent Encoded as Epithet}

....an extensive collection of Cookie Jars.

$\ldots$ as snow begins melting in early March...

...year-round recreational activities for the whole family...

There are endless ways to explore Rhode Island's rich cultural...

...Maine's protracted fall migration period...

\section{Extent as Part of a Nominal Group}

Visitors come to North Dakota for a variety of reasons...

The entire Peninsula has a rural nature...

The park's expansive 227 acres offers a series of wooded trails...

\section{Pre-modification of Quantifiers}

Eastern Idaho offers a wide variety of summer outdoor recreational activities and winter recreation.

...visitors will find this arts and cultural hub filled with a seeming endless array of arts and entertainment events.

Extent as an Attribute in a Relational Clause

The options to fill a day in this region are endless.

The outdoor recreational opportunities are limitless.

Extent Infused in Verbal Processes

Prices range from purely luxurious to comfortably affordable.

Extent as an Adverbial Expression Pre-modifying a Verbal Process

You immediately become a motorcycle enthusiast...

Closely located to downtown Chicago...

...has quickly become Georgia's premier mountain destination...

\section{Extent Encoded as a Prepositional Phrase}

... is scheduled to open by the end of 2013.

Known around the world as a literary Mecca...

You'll find wildlife and natural wonders both in and outside of its boundaries.

The 2013 season runs from May, 2013 through August 23, 2013. [?]

\section{Extent in Comparative Structures}

...it will take you more than a day to play your way through it all.

... National Forest is less than an hour's travel by car. 


\section{Extent Encoded as Numerical Attribute ...within a 30-mile radius of the city. See buffalo up close at the $\mathbf{4 0 0}$-acre preserve.. Then tour the $\mathbf{4 5 0 , 0 0 0 - s q u a r e - f o o t}$ production area...}

The use of the values of extent within the travel brochures could be explained in light of the fact that one of the strategies employed in promoting tourist destinations is their description in terms of their geographical condition; that is, how widely they are distributed over an area, how far they are from nearby attractions or services, how easily reachable they are, etc. The instances of extent in terms of time were also made use of for describing the extent of events over time as well as the time it takes tourists to go from one attraction area to another.

\subsubsection{Grammatical Structures Deployed in the Realization of Intensification}

As stated previously, when the attitudinal meanings are realized as a quality or a process, they can be graded as intensity. The following are examples of how intensity is realized in the language of travel brochures. Meanings are intensified in either of the two modes of infusing or isolating. The former refers to cases where no separate lexical form conveys the sense of up-grading or down-grading, while the latter concerns cases where an additional lexical item is added for the purpose of intensification (Martin and White 2005). Isolating and infusing realizations of intensification are exemplified below since they play an important part in reaching the overall purpose of tourism, that is, the purpose of promotion.

Pre-modification of an Adjective

...the dining choices are practically limitless.

Baton Rouge is a city where the weather is always warm, the food is always spicy and the people are always ready to have fun!

Pre-modification of an Adverb

Marine County is just a little out there.

Pre-modification of Quantifiers

There are so many ways to play in Massachusetts.

It is a quite little community in the heart of beautiful lake country.

Adverbially Modified Verbal Group

Experience the joy of providing your family with a vacation they'll never forget. You can almost hear the voices of residents...

Adverbially Modified Nominal Groups 
TOURISM DISCOURSE REVISITED: AN ANALYSIS OF EVALUATIVE STRATEGIES...

The winding River Road is merely a portal to the past.

...it can be quite a challenge to narrow down your pathway to fun and learning.

\section{Relative Scaling through Comparatives and Superlatives}

With respect to the second subcategory of force, namely, intensification, a great number of instances within the brochures deployed the superlative form of adjectives particularly the term best, suggesting that exaggeration is one of the significant strategies used in building a discourse about an attraction. Note the use of comparatives and superlatives in the examples below:

.... one of the finest museums in the world.

...hiking and boating that make the area most popular.

...why Atchison had more millionaires per capita than any town in the nation...

With some of the coolest museums on earth...

Intensifications can also be infused in verbal processes as in

...peaking during its last week

The verbal process peak is regarded as an instance of intensification in that it could be unpacked as reach the highest point.

\section{Maximization}

Maximisers were greatly deployed in the travel brochures as a means of intensifications. Intensifiers of this type are adopted to upscale processes and qualities as being at the highest possible degree of intensity (Martin and White 2005).

Lubbock is the West Texas you've always dreamed of...

...the most selective of tastes will find something absolutely delicious.

...enjoy the full richness and diversity of our Great River Road.

\section{Lexicalization}

Intensification is in some cases carried out not through the common grammatical intensifiers very, slightly, quite, fairly, but via lexical entities "carrying an attitudinal overtone" (Martin and White 2005: 143):

....as easily found as a miniature golf course.

And we proudly live our history.

....are welcome notes to this eagerly awaited season. 
....are reasonably easy to see through July.

...that perfectly capture the feeling and scenery of their American holiday.

Rural and urban experiences blend seamlessly...

Lexicalized items, as seen in the examples above, have within them the explicit attitude of the writer which is in line with the general purpose of promotion.

\section{Intensification via Repetition}

Missoula is that it is all that and more.

...making you feel at home and wanting to return again and again.

Des Moines is easy, Easy to afford, Easy to park, Easy to fall in love with.

The fact that repetition has a great influence in making people remember things is taken for granted. This strategy is deployed by tourist text developers to impact the memories of the potential tourists, and make them subconsciously remember their intended message. In the example above about Des Moines, we see how everything is attempted to be described as being easy through the strategy of repetition.

\section{Figurative Modifiers}

...Shoshoni River where you'll find kayaks and rafts enjoying the crystal clear waters as well.

...mountains covered in a rainbow of wildflowers.

Meanings were also found to be intensified through figurative modifiers. This is a crucial promotional pattern since the meanings being modified figuratively can affect the ideas of the clients by touching their feelings. This can raise the power of promotion.

\section{Infused Intensification}

As stated earlier, in some cases intensification is made through no separate lexical item, but the sense of upgrading is infused with other meanings within the sentence. In the first two examples that follow, infused intensification concerns quality while the next two instances are infused intensifications of process:

... offers a glimpse into the lives of America's longest lasting communal society...

... which have provided a lifetime of memories to generations of visitors.

...campgrounds are closed by the time winter blankets the area with snow.

... and indulge in delightful regional cuisine...

Unlike cases where intensification is made through the isolating mode, when meanings are intensified with no separate item they tend to influence the taste of the 
clients indirectly. In other words, when infused intensification is deployed in tourist texts, the purpose of promotion is served while the tourists may subconsciously be aware of it.

\subsection{GRAMMATICAL RESOURCES: FOCUS}

As MacCannel (1989) observes, the main tourists' motivation is the search for authenticity. For this reason, the language of tourism is stocked with different manifestations of authenticity which are all construed employing the second subsystem of Graduation, namely, focus. In other words, the subcategory of focus can act as an appraisal resource for construing the authenticity which is, according to Dann (1996), one of the four major theoretical approaches to the language of tourism. Graduation within the category of focus is concerned with sharpening or softening of categorical memberships of phenomena. The resources via which Graduation of this type was realized in the grammar of travel brochures are exemplified below:

\section{An Epithet in a Nominal Group}

...offers more than 40 miles of hiking and special programs.

The interior of the original section of the State House...

From major festivals to a wealth of unique shops and eateries...

Shopping in Sevierville is a must, especially because it is home to Tennessee's largest authentic outlet mall, Tanger Five Oaks.

\section{Pre-modification of a Nominalized Quality}

Warm smiles and genuine care for everyone are hallmarks of the area's southern hospitality.

An Adverbial Expression with a Clausal Scope

...especially because it is home to Tennessee's largest authentic outlet mall, Tanger Five Oaks.

...Arizona truly is a grand destination.

An Adverbial Expression Modifying an Attribute

The Small Ship Adventure Company offers truly memorable experiences for discerning travelers who value luxury, quality, and intimate up-close encounters.

\section{Infused Coding of Attributes}

...explore Kentucky's pivotal Civil War battles.

Abingdon is one of those quintessential All-American towns that people are drawn to for so many reasons.

...the twenty block historic downtown area is a focal point for both locals and tourists. 
To sum up, the results of the study revealed that the discourse of travel brochures is replete with the values of Graduation that serve as a strong tool in promoting various aspects of tourist destinations. In other words, in tourism discourse the overall aim is not giving information; all attempts are made in developing the travel brochures to promote the destinations and the services provided for the purpose of attracting a great number of holidaymakers.

\section{CONCLUSION}

The study provides support for the appraisal model itself and offers an approach to explaining the construal of Graduation values within the discourse of tourism. The model was also found to serve as a useful means to account for the diverse meanings and resources adopted in tourist brochures for the purpose of evaluation particularly due to the overuse of values of Graduation within tourist texts. In other words, the appraisal model provided an exhaustive framework to determine whether and in what ways evaluative strategies were encoded in travel brochures.

The study has potential weaknesses as well. As stated earlier, the brochures were selected from the websites of tour operators across the United States. Furthermore, only one brochure was selected as a representative of tourist texts from each state. This can be considered as a limitation for this study since, as Myers (1996: 59) argues, corpus-based studies of a large number of texts can "draw much more subtle relations between the various linguistic features than can be done in more intensive studies of a few texts". As a result, the greater the number of brochures, the more comprehensive would be the findings of the study. Besides, the corpus used in this study was limited in terms of the context. To arrive at any generalization about the discourse of tourism, similar studies need to be conducted in different cultures, in different English-speaking contexts, and in different languages. It is also noteworthy that the patterns which were considered as being scarce in this context, such as figurative intensifications, might turn out to be quite pervasive in other contexts due to potential variations in linguistic preferences of English and non-English tourist texts.

The format and the visual design of tourist brochures which were the concern of many multimodal studies across the literature were not incorporated into the present study. This could be linked to the intention of the researchers in analyzing only the language of tourism with a closer look.

Technology has facilitated our lives in various ways, including in the area of text analysis. In technology-assisted discourse studies, not only is the analysis facilitated, but also the risk of human error is, to a great extent, reduced. The 
present study, however, relied only on human evaluation for the purpose of text analysis.

The findings of the study suggest that language is used to influence potential clients of the tourism sector. Accordingly, certain preferences in terms of lexicogrammatical resources used in grading different values have been identified which serve to keep the content of travel brochures in line with tourists' expectations. The results of the study have a potential application to the growing body of future research on the evaluative language either in tourism discourse or discourses of other types. The resources outlined in this study for the coding of Graduation resources might serve as a point of departure for more comprehensive studies in the field of tourism discourse or be taken to evaluate other types of discourses. In addition, the resources introduced for the encoding of Graduation subsystems in this study can be used as a frame of reference for the staff and students within the tourism sector for the assessment of the effectiveness of tourist brochures. Moreover, it serves as a means to provide them with a clear understanding of the linguistic needs required in developing travel brochures. This might be equally an issue of concern to the stakeholders within tourism industry as their overall aim is to develop the most effective brochures.

The study might pave the path for future studies both in the domain of appraisals and tourism discourse. The work undertaken here can facilitate more detailed studies evaluating the patterns and resources favored in the promotional discourses of similar types within and across languages. Furthermore, the study is expected to provide an opportunity for testing the efficiency of the framework as a tool for text analysis.

\section{REFERENCES}

A'Beckett, L. 2010. "Appraisal in the Russian press: The characterization of the Ukranian leaders". Revista Electrónica de Lingüística Aplicada 8: 102-119.

Bednarek, M. 2010. "Polyphony in APPRAISAL: Typological and topological perspectives". Linguistics and the Human Sciences 3(2): 107-136.

Bhatia, OV K. 1993. Analyzing genre: Language use in professional setting. London: Longman.

Bruner, E. M. 1991. "Transformation of self in tourism". Annals of Tourism Research 18: $238-250$.

Burns, A. L. and R. A. Robertson. 1999. "An evaluation of state tourism websites". Proceedings. The Northeastern Recreation Research Symposium, 1999. 17-22. 
Ciu, H., Lu, D. and Y. Hong. 2012. "A Contrastive Case Study of Cohesion in English and Chinese Tourist Texts". Proceedings of the International Conference on Engineering and Business Management. 2486-2489.

Choi, S., Xinvan, Y. L. and M. M. Alastair. 2007. "Destination image representation on the web: content analysis of macau travel related websites". Tourism Management 28: 118-129.

Dann, G. 1996. The language of tourism: A sociolinguistic perspective. Wallingford, U.K.: CAB International.

Dann, G. 2012. "Remodelling a changing language of tourism: From monologue to dialogue and trialogue". Revista de Turismo y Patrimonio Cultural 10: 59-70.

Dillard, J. P. and M. Pfa. 2002. The persuasion handbook: Developments in theory and practice. California: Thousand Oaks.

Doolin, B., Burgess, L. and J. Cooper. 2002. "Evaluating the use of the web for tourism marketing: A case study from New Zealand". Tourism Management 23 (5): 557-561.

Dore, L. and C. I. Crouch. 2003. "Promoting destinations: An exploratory study of publicity programs used by national tourism organizations". Journal of Vacation Marketing 9: 137-151.

Gotti, M. 2003. Specialized discourse. Bern: Peter Lang.

Hallett, R. W. and J. Kaplan-Weinger. 2010. Official Tourism Websites: A Discourse Analytical Perspective. Bristol: Channel View Publications.

Hood, S. 2004. Appraising research: Taking a stance in academic writing. Ph. D. Thesis. Faculty of Education, University of Technology, Sydney.

Hood, S. 2006. "The persuasive power of prosodies: Radiating values in academic writing”. Journal of English for Academic Purposes 5: 37-49.

Hood, S. and J. R. Martin. 2007. "Invoking attitude: the play of graduation in appraising discourse". Continuing Discourse on Language: A functional perspective (Volume 2). Eds. R. Hasan, C. Matthiessen and J. Webster. London: Equinox Publishing. 739-764.

Jalilifar, A.L., Hayati, A.M. and A. Mashhadi. 2012. "Evaluative strategies in Iranian and international research article introductions: Assessment of academic writing”. RALS 3 (1): 81-109.

Jonsson, S. and J. Syssner. 2011. "Postkolonialism". Perspektiv på turism och resande. Begrepp för en kritisk turismanalys. Ed. J. Syssner. Lund: Studentlitteratur. 215-236.

Kress, G. and T. Van Leeuwen. 1996. Reading Images: The grammar of visual design. London: Routledge. 
TOURISM DISCOURSE REVISITED: AN ANALYSIS OF EVALUATIVE STRATEGIES...

Lähteenmäki, S. 2012. Experience the real New Zealand-Maori culture as it is today: Representations of New Zealand and Maoris in Maori tourism websites. Master's thesis. University of Jyväskylä, Department of Languages.

Liu, L. and M. Stevenson. 2013. "A cross-cultural analysis of stance in disaster news reports". Australian Review of Applied Linguistics 36(2): 197-220.

Liu, X. 2013. "Evaluation in Chinese university EFL students' English argumentative writing: An APPRAISAL Study". Electronic Journal of Foreign Language Teaching 10: $40-53$.

Locksley, G. 2009. The media and development: What's the story? Washington, D.C.: The World Bank.

MacCannel, D. 1989. "Introduction". Annals of Tourism Research 16: 1-6.

Macken-Horarik, M. 2003. "Appraisal and the special instructiveness of narrative". Text 32: 285-312.

Martin, J. R. and P. White. 2005. The language of evaluation: Appraisal in English. New York: Palgrave.

Mei, W. S. and D. Allison. 2003. "Exploring appraisal in claims of student writers in argumentative essays". Prospect 18 (3): 71-91.

Mocini, R. 2009. "The verbal discourse of tourist brochures". Annals of Tourism Research 5: 153-162.

Myers, G. A. 1996. "Strategic vagueness in academic writing". Academic Writing: Intertextual and Textual Issues. Eds. E. Ventola and A. Mauranen. Amsterdam: John Benjamins. 3-18.

Pan, S., Tsi, H. and J. Lee. 2011. "Framing New Zealand: Understanding tourism TV commercials". Tourism Management 32: 596-603.

Patpong, P. 2009. "Thai persuasive discourse: A systemic functional approach to an analysis of amulet advertisements". Revista Alicantina de Estudios Ingleses 22: 95-217.

Rokowski, E. P. 2001. "Tourism as a language of social control". Simposio Internacional de Comunicación Social. Ponencia invitada. Santiago de Cuba, 22-26 enero 2001.

Said, E. W. 1991. Musical Elaborations. New York: Columbia University Press.

Santos, C. A., Belhassen, Y. and K. Caton. 2009. "Reimagining Chinatown: An analysis of tourism discourse". Tourism Management 29: 1002-1012.

Scollon, R. and P. Levine. 2004. "Multimodal discourse analysis as the confluence of discourse and technology". Discourse and Technology: Multimodal Discourse Analysis. Eds. P. Levine and R. Scollon. Washington, D. C.: Georgetown University Press, 1-6. 
Thurot, J. 1989. Psychologie du Loisir Touristique. Aix-en-Province: Centre des Hautes Etudes Turistiques.

Van Leeuwen, T. 2004. "Ten reasons why linguists should pay attention to visual communication". Discourse and Technology: Multimodal Discourse Analysis. Eds. P. Levine and R. Scollon. Washington, D. C.: Georgetown University Press, 7-9.

Wan, Y. N. 2008. "The exchange of interpersonal meaning in call center conversations". Odense Working Papers in Language and Communication 29: 825-839.

White, P. R. R. 2001. "Appraisal: An overview". <http://www.grammatics.com/ appraisal/AppraisalGuide> .

White, P. R. R. 2003. "Appraisal: The language of attitudinal evaluation and intersubjective stance". <http://www.grammatics.com/appraisal>.

Yui Ling Ip, J. 2008. "Analyzing tourism discourse: A case study of a Hong Kong travel brochure”. LCOM Papers 1: 1-19.

Zikmund, W. G. 2008. Business Research Methods. Ohio: Thomson South-Western. 